\title{
New perspective of learner-centered education in nowadays didactics
}

\author{
Elena Lucia Mara ${ }^{1, *}$ \\ ${ }^{1}$ Lucian Blaga University of Sibiu, Teacher's Training Department, 34 Calea Dumbravii, Sibiu, \\ Romania
}

\begin{abstract}
An approach to education that is based on the educational context in which the student comes and track progress in achieving the learning objectives. The learner-centred education learning places the responsibility on the shoulders of students, while the teacher takes responsibility for facilitating the education process. The approach tends to be unique, flexible, competency-based methodology and not always varied in time and space constrained. Teaching will have complex changes, so if, traditionally, it is just a business communication / transmission of knowledge, actual perspectives follows specifically aims in organizing and managing learning processes. According to the researchers in the field, developing paradigm / meanings in teaching practice in teaching, learning and assessment, respectively constructivist paradigm and the paradigm of interactive, make an important contribution. A student-centred educational activity is if it satisfies the following requirements: it is based on personal characteristics of the students; it aims at developing skills (main objective) and transmission of specific content (secondary); contribute actively student in planning, execution and evaluation of them; it is a positive learning experience; and allows transfer of experience to another educational situation. As a general matter, the way of learning is the way of influence how students learn how to teach; also, the content being taught (notions, concepts, procedures, problem solving, attitudes etc.) must determine how to present the information, and the logical sequence and structure, while achieving effective transposition of internal staff. The teacher is no longer just providing information to the student (what to teach but also to help students how to learn).
\end{abstract}

\section{Modern Didactics}

The concept of Modern Didactics, develops under the impact of developments in psychology and sociology, with emphasis on the action of learning, with the two protagonists, the teacher and the student. The focus is on the interaction teacher - student in the action of teaching and learning. Miron Ionescu believes that "modern/current didactics incorporates the entire scope of traditional didactics and extends its content through:

- Studying the formal and even informal educational influences;

\footnotetext{
${ }^{*}$ Corresponding author: 1ucia.mara@,ulbsibiu.ro
} 
- Valuing the elements that ensure self - instruction (and self-education);

- Studying the issue of instruction and education for all age groups" [1].

Easy to understand why modern didactics concerns include new challenging themes that also aim interdisciplinary approaches, such as: learning by machines, instruction and selfinstruction computer-assisted; multimedia learning; using technical means training and self - training; pedagogical programming; studying the effectiveness of different ways of organizing the instructive - educational activities. Comparative analysis between traditional didactics and modern didactics also changes the general concept on the teaching-learning process. It goes from the conception of magistro-centrist type at that of psycho-centrist or socio-centrist. Modern didactics becomes a didactic of active participative methods, where the student becomes an active subject of his own training, trained in all phases of the educational process. In formal and informal contexts; exploiting certain forms of work that are complementary to the lesson, training the rational style of intellectual work; leisure pedagogy; self-training, etc.

\section{Nowadays Didactics}

The post modernization effect of the school is seen as a current solution because focuses as a centre of all concerns the student/subject of research, but not an abstract, ideal student that is out of the reality in which he lives, but a specific student with his difficulties and achievements. In agreement with these the school must also meet the requirements of the individual. The idea is captured very well by E. Paun, "we can speak of a return of the individual as an actor in the social space and a resurrection of the student as a person with his specific - differentiating features that have to be maximal valued, constitutes the dominant dimension of postmodern pedagogy" [2]. This remembrance of the beginnings of traditional didactics to the postmodern one, emphasizes the evolution of didactics concept, evolution that captures the ample openings and meanings that were captured over time by the fundamental processes (teaching, learning, assessment) of education, main actors (student and teacher) and the very concept of educational process.

General school didactics focuses on school practice experience, illustrated in methodical guides, rules that apply to the learning process as a whole. It also, designates necessary principles for this process, ensuring the basis for developing special didactics of specialty, also offering the required orientation to solve specific issues of any special didactics. Thus, general didactics offers to special didactics the necessary theoretical basis, guiding framework: knowledge, guidelines, trends, norms, rules, principles, etc. Special didactics of specialty, target specific issues arising from the application of general school didactics in different subjects, namely: educational objectives of their teaching and learning, specific content, specific teaching principles, appropriate methodology and assessment. Special didactics of specialty do not support the takeover, rigid and uniform application of general didactics recommendations, but focus on their application. Make available practical material for theoretical developments and generalizations of general school didactics. Between general school didactics and special didactics of specialty are determined interdependence relationships. Pedagogic training of a teacher can not be restricted to special teaching. It must include the theory of objectives, forms and teaching technologies, knowledge of human development factors, of its bio-psycho-socio-educational condition.

Moving to university didactics, we note that it "analyzes the processes of scientific teaching and learning, taking account of the organizational conditions of personnel, content, methods and teaching materials, recommending, based on research, effective means of teaching, learning and assessment" [3]. It became increasingly apparent the awareness of the need for pedagogical culture, at university level, overcoming the prejudgments according to that the training of necessary pedagogical skills at university level would 
require only knowing the taught specialty. Miron Ionescu shows that macro pedagogy/pedagogy of systems, "perceives the school as a whole comprehensive integrated subsystem of the society"; micro pedagogy/learning pedagogy and self-learning "addresses in mono - or interdisciplinary manner the learning, fundamental human activity, decisive in solving all social problems" [1].

The trends of modern didactics have known an explosive growth also in today's society, so we enumerate the premises of these developments by identifying in the literature, the following directions:

- Action of prospecting, as a way of anticipative studying of training and education of future society. G. Vaideanu, characterizes training and education "are ordered more and more by the future" [4], which requires, obviously, the need of their exploring their future society. "Until now", M. Ionescu said, "pedagogical research studied more the state than the change, adaptation than creation, the present than the future, the state of things that cannot be accepted" [5].

- The comprehensive, inclusive and global approach of the training and education process, namely, its components.

- Focusing the educational research on learning, in structural and functional relationship with teaching and assessment. It speaks more and more now that learning causes teaching (teaching should meet the needs of learning), and that assessment should assist, regulate, direct and optimizes the process throughout its duration and through this, and trainee's performances.

- In agreement with the theory of curriculum, redesigning the existing relations in the educational process between the "subject" and "object" of education, between the scheduled studied discipline and its formative effects on short, medium and long term.

- Re-assessment and selection of content education both in the sense of its openness to the "new educations", as well as its selection after the formative value and, especially the restriction by deepening the reference sphere of education content to specific pedagogical values.

- Defining the content of education by its reporting to all types of curriculum specific to an efficient education: common curriculum - differentiated curriculum; compulsory curriculum - school curriculum; formal curriculum - curriculum informal etc.

- Identifying certain working strategies and some forms of organization of teaching activity that responsibly engage students, while being operant and productive. Learning by cooperation asks for relational components of activity and better values the intellectual potential, of initiative and creativity of students, forming at the same time, availability of communication and cooperation.

\section{Educational System}

Also in the Romanian education system, the framework of curricular and extracurricular educational activity constitutes the space that is able to meet the challenges of contemporary society, in the extent in which its flexible conception allows a continuous update of content learning and student-centred teaching methods and also a monitoring and assessment of learning outcomes. Also, specific features facilitate the implementation of new teaching approaches by which the student becomes a resource, producer, opinion leader, so active participant. To stimulate the cognitive, spiritual, interpersonal and social development, the educational and extracurricular educational activity has always the need to adapt to individual requirements, different of all children, to the interests of knowledge and to their potential.

The strategy emphasizes the importance of multiplying the positive experiences registered in school and extracurricular educational activities and requires the extension of 
the intervention space in the educational curriculum process, in order to capitalize all educative strengths of educational learning content in the best interests of the child. Comparing the traditional view on the instructive educative activity and that on the differentiated activity, including that centred-on student/learning subject, in order to highlight the impact of the latter on the development of the student in relation to own potential, it signalled the difference between them [6].

Table 1. Comparative presentation, traditional educational - instructional activity and differentiated activity

\begin{tabular}{|c|c|}
\hline $\begin{array}{c}\text { Traditional educational - instructional } \\
\text { activity }\end{array}$ & Differentiated activity \\
\hline $\begin{array}{l}\text { - The differences between students are } \\
\text { masked; Is acted upon them only when } \\
\text { they become problematic; } \\
\text { - The interests of the child are rarely called; } \\
\text { - Dominates the work with the entire class }\end{array}$ & $\begin{array}{l}\text { Differences between students are studied } \\
\text { and accepted as a start in the instructive - } \\
\text { educational process; } \\
\text { - Students are guided to their own interests } \\
\text { and purposes of the elections guided by } \\
\text { them; } \\
\text { Are used different forms of organization of } \\
\text { work groups, teams, frontal or individual. }\end{array}$ \\
\hline - Time is inflexible. & $\begin{array}{l}\text { Time is flexible, according to the students' } \\
\text { needs. }\end{array}$ \\
\hline $\begin{array}{l}\text { - Are allowed unique interpretations of } \\
\text { ideas and events }\end{array}$ & $\begin{array}{l}\text { Are allowed, even are searched multiple } \\
\text { perspectives on events and ideas. }\end{array}$ \\
\hline $\begin{array}{l}\text { The teacher directs the student's } \\
\text { behaviour. }\end{array}$ & $\begin{array}{l}\text { The teacher facilitates the independent } \\
\text { activity of students. }\end{array}$ \\
\hline - The teacher solves his class issues. & $\begin{array}{l}\text { - The students help each other, assisted in } \\
\text { solving issues. }\end{array}$ \\
\hline $\begin{array}{l}\text { - The teacher plans sequences, training } \\
\text { objectives, provides standards for } \\
\text { assessing the work. }\end{array}$ & $\begin{array}{l}\text { Students work together with teachers to } \\
\text { establish goals and assessment criteria. }\end{array}$ \\
\hline - Observe what should be learned & Observe for whom they learn. \\
\hline
\end{tabular}

Also from a systemic perspective, any educational situation is a system of transactions and simultaneous interactions between the subject of education, the object of education and environment. Such an approach is useful in understanding that any particular situation has several features [7]:

- It is determined by the purposes of education;

- It is dependent on the personal characteristics of the student and teacher;

- Is oriented to achieve certain specific goals;

- It is limited by strategic options, methods, instruments and forms of organization that are available and used;

- It is possible within the limits of the socio-cultural-educational context.

Table 2. The object of education and environment

\begin{tabular}{|c|c|c|c|}
\hline Purposes & $\begin{array}{c}\text { Personal } \\
\text { characteristics }\end{array}$ & $\begin{array}{c}\text { Needed cognitive } \\
\text { processes }\end{array}$ & Type of learning \\
\hline Learn to learn & I know that I know & Metacomponents & Metalearning \\
\hline Learn what is & What I already learn & $\begin{array}{c}\text { Acquisition } \\
\text { components }\end{array}$ & Declarative learning \\
\hline Learn how to do & What can I do & $\begin{array}{c}\text { Performance } \\
\text { components }\end{array}$ & Procedural learning \\
\hline
\end{tabular}


The teaching activity acquires more complex changes, so if, traditionally, it is just a communication/transmission activity of knowledge, now mostly aims the organization and management of learning processes. According to researchers in the field, developing paradigm/meanings in teaching practice, in teaching activity, in learning and assessment, namely the constructivist paradigm and the interactive paradigm, have an important contribution. In the didactics of science, specifically, it is found that in not emphasized enough the process of building knowledge, but is especially focused on the transmission and acquisition of content of school subjects through mere accumulation of data, facts, information, by use of expository strategy of introducing and explaining concepts. According to researchers in the field, developing certain paradigms/meanings in teaching practice, in teaching, learning and assessment activity, namely constructivist paradigm and interactive paradigm, make an important contribution. In teaching science, it is found that is not insisted enough on the process of building knowledge, but is especially focused the process of transmission and acquisition of content of school subjects through the mere accumulation of data, facts, information, by the use of expository strategies of introduction and explanation of concepts.

\section{Learner Centred Perspective}

Thus, the researches of cognitive psychology, have an important contribution in increasing the quality of teaching and learning activities. The major characteristic of constructivism is the centred approach on the one that is educated, namely on its activity of building the knowledge, the focus is on individual construction of personal knowledge, on the way that the person acquires knowledge. In other words, the subject customizes the working methods and builds strategies of action tailored to its own training and personality. Musata Bocos, 2002, shows the design of constructivist concept through a set of principles [8]:

- Supporting the subject of knowledge to acquire experience in the process of building knowledge.

- Supporting self-awareness for the building process of knowledge.

- Promotion the use of multiple modes of representation.

- Inclusion of learning in social experience.

- Encourage the subject of knowledge to organize its own learning process and to be involved in its development.

- Contextualization of learning in real and relevant frameworks for the knowing subject.

- Supporting the subject of knowledge to gain experience across the multiple perspectives of addressing topics and appreciation/assessment thereof.

Also, constructivist teaching highlights the focus on student - centred and the teacher pays special attention to pupils' motivation, skills training for autonomous learning and even a certain freedom to choose beyond the core compulsory curriculum, certain disciplines of learning, namely specific contents that they want to learn or other auxiliary that they use. In essence, the entire teaching process becomes one centred on person which means: on the one hand, investigating the knowledge base of the student, knowledge of his cognitive peculiarities; on the other hand, in relation with the identified needs, contents are adapted and the strategies are taught, learning and assessment are individualized.

As a general matter, the way the students learn influences the way in which it should be taught; also, the content that should be taught (notions, concepts, procedures, problem solving, attitudes etc.) determine the way information should be described, logical sequence and structure, and in the same time, effective achievement on internal didactics transposition. The teacher does not only provide information to the student (what to learn, but also helps students how to learn). In this context, contemporary pedagogy in connection with cognitive psychology and to modalities of activation of students proposes the 
reconsideration of the learning activity, as a fundamental activity. Learning is described as an individual process, it is done through direct experience with environmental situations; It is strongly determined by previous knowledge base and the teaching process becomes one centred on the learner. Ioana Todor quoting Jonassen, 1994, presents the learning environment characteristics in terms of constructivist theories:

- to offer multiple representations of reality (contributing to the increase of the cognitive flexibility);

- these multiple representations should be adaptive, preventing over - simplification and showing real environmental complexity;

- to facilitate the construction of knowledge in instead of their reproduction;

- to facilitate the solving of genuine tasks in relevant contexts, instead of abstract decontextualized instruction, to involve the application of opened and authentic teaching methods, like laboratory investigation or case study in lieu of rigidly structured methods;

- to encourage the personal reflection on experience;

- to allow the construction of knowledge associated with different contexts of learning;

- to facilitate the collaborative construction of knowledge by the social negotiation of significations [9].

Learning, is achieved in a direct interaction with the environment, proposes a direct experience where the subject is actively involved, these are conditions which ensure success in the learning activity. The constructivist teachers emphasize the need for the process of building schemes/structures of knowledge, knowledge personalization, and student role is to reflect to the new material by using cognitive strategies and metacognitive strategies in their assimilation. Essentially, the constructivist dimension makes two fundamental issues with a focus on which that one that represents the focus on the student, namely: the subject builds knowledge within its own activities; and the activity aims its own knowledge through the elaboration of knowledge by the student himself. As a complementary to the constructivist pedagogy we also enunciate the role of active and interactive learning promoted by the interactive instruction. As Serbanescu Laura highlights, "modern didactic recommends that learning performed by students to be active and interactive, to assume the full involvement of students - intellectual, motor and affective-volitional, to be based on practical activities and experiments, to be achieved by intra - and interdisciplinary connections on an heuristic and problematical context, to stimulate active, critical and creative thinking of students" [10].

\section{Conclusions}

Thus, the paradigm of student-centred learning determines the need for decentralization and autonomy of education, namely the need for an educational system organized after the model of the network that provides the opportunity for a real adaptation to the needs and possibilities of the student, promoting inclusive school, to social changings through the high level of adaptability of graduates or by focusing on skills and social requirements through the wide range of diversity of "inputs" and "outputs" in the system.

The paradigm of school adaptation to the requirements and possibilities of training of student represents the product of flexible structure of the system, but also the result of multiplying the types of curriculum.

The programs that reflect the flexibility assumed by the network organized educational systems are the open school, school/education for all, inclusive school, school centred on resources, integrated teaching and especially the constructivist paradigm, the paradigm of interactive training etc. 


\section{References}

1. M. Ionescu, M. Bocos, Tratat de didactica moderna (Parallel 45 Pub., Pitesti, Romania, 2004)

2. E. Paun and D. Potolea, O lectura a educatiei prin grila postmodernitatii. Pedagogie. Fundamentari teoretice si demersuri aplicative (Polirom Pub., Iasi, 2002)

3. Dictionary of Pedagogy (2001)

4. G. Vaideanu, Educatia la frontiera dintre milenii (Political Pub., Bucharest, 1988)

5. M. Ionescu, Didactica moderna (Dacia Pub., Bucharest, 2003)

6. A. Rotaru, L. Soitu, Psihologia elevului (Timisoara, 2002)

7. M. Predescu, L. Soitu, Psihologie, (Ex Ponto Pub., Timisoara, 2006)

8. M. Bocos, Instruirea interactiva. Repere pentru reflectie si actiune, 2nd Ed. (P.U.C., Cluj Napoca, 2002)

9. I. Todor, Invatarea de la adulti. Aplicatii in didactica universala, In Ghid metodologic de pedagogie universitara (Aeternitas Pub., Alba Iulia, 2010)

10. L. Serbanescu, Conferinta Nationala de educatie a adultilor, Timisoara, 2010 